\title{
Influence of Pruning Intensity and Foliar Application of Nutrients on Growth, Yield and Sugar Content of Phalsa (Grewia subinaequalis D.C.)
}

\author{
Shashank Singh* and H.K. Singh \\ Department of Horticulture, N.D. University of Agriculture and Technology, \\ Kumarganj, Faizabad- 224229 (U.P.), India \\ *Corresponding author
}

\begin{tabular}{|c|c|}
\hline & A B S T R A C T \\
\hline & The experiment was conducted to study the effect of different levels of pruning and foliar \\
\hline Keywords & D.C.). The pruning level at $25 \mathrm{~cm}$ above ground level had significantly maximum shoot \\
\hline $\begin{array}{l}\text { Foliar feeding, } \\
\text { Phalsa, Pruning } \\
\text { intensity, Quality, } \\
\text { Yield. }\end{array}$ & $\begin{array}{l}\text { length }(210.25 \mathrm{~cm}) \text { and number of leaves per shoot }(85.27) \text {. While, number of shoots per } \\
\text { plant }(30.60) \text { was recorded highest with pruning at } 50 \mathrm{~cm} \text { above ground level. Moreover, } \\
\text { reducing sugars }(12.95 \%) \text {, total sugar contents }(16.50 \%) \text { and fruit yield per hectare }(62.39 \\
\text { q/ha) were recorded high with pruning at } 50 \mathrm{~cm} \text { above ground level. Regardless of severity }\end{array}$ \\
\hline Article Info & $(213.83 \mathrm{~cm})$, number of shoots per plant $(32.22)$, and fruit yield per ha $(63.26 \mathrm{q} / \mathrm{ha})$. While, \\
\hline $\begin{array}{l}\text { Accepted: } \\
\text { 24 February } 2017 \\
\text { Available Online: } \\
10 \text { March } 2017\end{array}$ & $\begin{array}{l}\text { number of leaves per shoot }(90.44) \text { was noted maximum with toliar spray of urea }(2.0 \%) \text {. } \\
\text { All quality parameters viz., reducing sugars }(13.43) \text {, total sugar contents }(17.12) \text { were } \\
\text { better with } \mathrm{ZnSO}_{4}(0.4 \%) \text {. The interaction effect of pruning levels and chemicals spray on } \\
\text { total sugar contents and fruit yield per ha was found significant and the maximum total }\end{array}$ \\
\hline & $\mathrm{ZnSO} 4(0.4 \%)$ along with pruning at $50 \mathrm{~cm}$ above ground level. \\
\hline
\end{tabular}

\section{Introduction}

Phalsa (Grewia subinaequalis D.C.), is popular fruit in subtropical and tropical regions and can be grown throughout the country (Singh, 1992; Singh and Singh, 2003). Phalsa which is also known as star apple belong to family Tilliaceae. The family has about 41 genera and 400 species. Phalsa plant is indigenous to India. Phalsa is small bush that bears many small berries like fruits of deep radish purple color. It is a rich source of vitamins $\mathrm{A}$ and $\mathrm{C}$ and comes in market in June when other fresh fruits are not available (Sharma et al., 2008). Children use its fruit as table fruit, otherwise; basically it makes ready-to-serve, beverages like juice, squash, syrup etc. (Singh et al., 2006). Ripe fruits are acidic in taste and containing 50-60\% juice, $10-11 \%$ sugars and $2-2.5 \%$ acid. It is one of the hardiest fruit crop and does not affected by any insects, pest and disease. Phalsa can be grown as an intercrop with mango, aonla, bael and ber.

The continuous application of amount of chemical fertilizers hampers the fruit quality, soil health and generates pollution. Considering these points there is need to initiate the nutrient management programmed 
to increase berry size, uniform ripening, and higher fruit yield to improve the quality of fruits. In addition to nutrients, pruning intensity has also been reported to manage plant canopy and enhance the flowering, fruiting, yield and quality of many fruit crops (Singh and Singh, 2008 and Ali et al., 2001). Keeping in view, enhancing the yield and quality in Phalsa, the investigation was undertaken. The objective of present investigation was to study the effect of pruning intensity and foliar feeding of different nutrients on growth, yield and quality of phalsa cv. Sharbati.

\section{Materials and Methods}

The present investigation was carried out to investigate "Effect of pruning intensity and foliar feeding of nutrients on growth, yield and quality of phalsa (Grewia subinaequalis D.C.)". The experiment was conducted at Main Experiment Station, Department of Horticulture, Narendra Deva University of Agriculture and Technology, Kumarganj, Faizabad (U.P.) during 2010-11 growth season. Twenty years old uniform phalsa plants cv. Sharbati, planted at $3 \times 2 \mathrm{~m}$ apart were used as experimental material for the present investigation. One plant was taken as unit per plot. Fifteen treatments were taken for the study viz., $\mathrm{T}_{1}: 25 \mathrm{~cm}+$ Water spray, $\mathrm{T}_{2}$ : $25 \mathrm{~cm}+\mathrm{ZnSO}_{4} 0.4 \%, \mathrm{~T}_{3}: 25 \mathrm{~cm}+\mathrm{CuSO}_{4}$ $0.4 \%, \mathrm{~T}_{4}: 25 \mathrm{~cm}+\mathrm{K}_{2} \mathrm{SO}_{4} 0.2 \%, \mathrm{~T}_{5}: 25 \mathrm{~cm}+$ Urea $2.0 \%, \mathrm{~T}_{6}: 50 \mathrm{~cm}+$ Water spray, $\mathrm{T}_{7}: 50 \mathrm{~cm}$ $+\mathrm{ZnSO}_{4} 0.4 \%, \mathrm{~T}_{8}: 50 \mathrm{~cm}+\mathrm{CuSO}_{4} 0.4 \%, \mathrm{~T}_{9}$ : $50 \mathrm{~cm}+\mathrm{K}_{2} \mathrm{SO}_{4} 0.2 \%, \mathrm{~T}_{10}: 50 \mathrm{~cm}+$ Urea $2.0 \%, \mathrm{~T}_{11}: 75 \mathrm{~cm}+$ Water spray, $\mathrm{T}_{12}: 75 \mathrm{~cm}+$ $\mathrm{ZnSO}_{4} 0.4 \%, \mathrm{~T}_{13}: 75 \mathrm{~cm}+\mathrm{CuSO}_{4} 0.4 \%, \mathrm{~T}_{14}$ : $75 \mathrm{~cm}+\mathrm{K}_{2} \mathrm{SO}_{4} 0.2 \%, \mathrm{~T}_{15}: 75 \mathrm{~cm}+$ Urea $2.0 \%$. Pruning was done in first week of February 2011 and first spray of nutrients was done in second fortnight of March 2011 (Pre blooming stage) and second spray just after fruit setting. The experiment was laid out in Randomized Block Design (factorial) with three replications. At the end of the growing season, each plant was evaluated in terms of the shoot length, number of shoot per plant, number of leaves per shoot, reducing sugars $(\%)$, total sugars (\%) and fruit yield per hectare (q/ha). The reducing sugars and total sugars were estimated by using the procedure given in AOAC (1990). Data were tested for normality, and then subjected to analysis of variance (ANOVA) suggested by Gomez and Gomez (1984). Significant differences between mean values were determined using the randomized block design and following two-way ANOVA.

\section{Results and Discussion}

The maximum (Table 1) shoot length (213.83 $\mathrm{cm})$ was recorded with foliar spray of $\mathrm{ZnSO}_{4}$ $(0.4 \%)$ treatment and statistically at par with application of Urea (2.0\%) and $\mathrm{CuSO}_{4}$ $(0.4 \%)$. The minimum $(202.37 \mathrm{~cm})$ shoot length was recorded with water spray. The pruning levels also showed significant effect on shoot length of phalsa. The maximum shoot length $(210.25 \mathrm{~cm})$ was recorded at pruning $25 \mathrm{~cm}$ above ground level and statistically at par with pruning at $50 \mathrm{~cm}$ above ground level while, minimum $(207.23 \mathrm{~cm})$ shoot length was recorded at pruning $75 \mathrm{~cm}$ above ground level $\left(\mathrm{P}_{3}\right)$. The interaction of pruning levels and chemical spray was found non-significant. The present findings were in conformity with Pankaj et al., (2009) and Rathore et al., (2008) in phalsa.

Significantly maximum (Table 2) number of shoots per plant (32.22) was recorded with foliar spray of $\mathrm{ZnSO}_{4}(0.4 \%)$ closely followed by (32.11) application of Urea (2.0\%) while, minimum number of shoots/plant (23.44) was recorded with water spray. In case of pruning levels, the maximum number of shoots per plant (30.60) was recorded with pruning at $50 \mathrm{~cm}$ above ground level closely followed by (29.27) pruning at $25 \mathrm{~cm}$ above ground level 
while minimum number of shoots per plant (28.27) were recorded with pruning at $75 \mathrm{~cm}$ above ground level $\left(\mathrm{P}_{3}\right)$. The interaction of pruning levels and chemical spray was found non-significant. These findings were in conformity with Kumar et al., (2004) in litchi and Rathore et al., (2008) in phalsa.

The maximum (Table 3) number of leaves per shoot (90.44) was noted with foliar spray of Urea (2.0) followed by spray of $\mathrm{K}_{2} \mathrm{SO}_{4}(0.2)$. The minimum (73.11) numbers of leaves per shoots were recorded with water spray. Different pruning levels also had interesting influence on number of leaves per shoot and highest number of leaves (85.27) was noted with pruning at $25 \mathrm{~cm}$ above ground level followed by pruning at $50 \mathrm{~cm}$ above ground level. The lowest number of leaves (81.20) was recorded with pruning at $75 \mathrm{~cm}$ above ground level $\left(\mathrm{P}_{3}\right)$. Combined interaction effect of pruning levels and chemical application was found to be non-significant. The findings were in agreement with Kumar et al., (2004) in litchi and Pankaj et al., (2009) in phalsa.

The maximum (Table 4) reducing sugars (13.43) were recorded with the spray of $\mathrm{ZnSO}_{4}$ (0.4) and statistically at par with application of $\mathrm{K}_{2} \mathrm{SO}_{4}$ (0.2) while, the value was minimum (11.34) with water spray. Pruning levels also influenced significantly reducing sugars. The maximum reducing sugars (12.95) were recorded with pruning at $50 \mathrm{~cm}$ above ground level followed by pruning at $25 \mathrm{~cm}$ above ground level and minimum (12.37) with pruning at $75 \mathrm{~cm}$ above ground level. The interaction effect of pruning levels and chemicals spray on reducing sugars was found non-significant. Similar findings were also reported by Singh et al., (1979) in grapes and Bhatia and Yadav (2005) in ber.

Total sugar contents (Table 5) were influenced significantly by chemicals spray and pruning levels. The maximum total sugar contents (17.12) was recorded with foliar spray of $\mathrm{ZnSO}_{4}(0.4)$ and statistically at par with application of $\mathrm{K}_{2} \mathrm{SO}_{4}(0.2)$ while, the minimum of total sugars (14.45) were recorded with water spray. Different pruning levels also significantly influenced the total sugar contents in phalsa fruits. The maximum total sugar contents (16.50) were recorded with pruning at $50 \mathrm{~cm}$ above ground level followed by pruning at $25 \mathrm{~cm}$ above ground level and minimum total sugar content (15.77) was recorded with pruning at $75 \mathrm{~cm}$ above ground level.

Table.1 Effect of pruning intensity and foliar feeding of nutrients on shoot length

\begin{tabular}{|c|c|c|c|c|}
\hline \multirow{2}{*}{ Treatments } & \multicolumn{3}{|c|}{ Pruning (Above ground level) } & \multirow{2}{*}{ Mean } \\
\hline & $25 \mathrm{~cm}\left(\mathbf{P}_{1}\right)$ & $50 \mathrm{~cm}\left(\mathbf{P}_{2}\right)$ & $75 \mathrm{~cm}\left(\mathbf{P}_{3}\right)$ & \\
\hline $\mathrm{C}_{0-}$ Control (water spray) & 204.33 & 203.27 & 199.51 & 202.37 \\
\hline $\mathrm{C}_{1 .} \mathrm{ZnSO}_{4} 0.4 \%$ & 215.00 & 213.88 & 212.60 & 213.83 \\
\hline $\mathrm{C}_{2-} \mathrm{CuSO}_{4} \mathrm{0.4 \%}$ & 210.92 & 210.33 & 208.88 & 210.04 \\
\hline $\mathrm{C}_{3}-\mathrm{K}_{2} \mathrm{SO}_{4} 0.2 \%$ & 208.00 & 207.95 & 203.82 & 206.59 \\
\hline $\mathrm{C}_{4-}$ Urea $2.0 \%$ & 212.30 & 213.00 & 211.37 & 212.22 \\
\hline Mean & 210.25 & 209.55 & 207.23 & \\
\hline & $\mathbf{P}$ & $\mathbf{C}$ & \multicolumn{2}{|c|}{$\mathbf{P} \times \mathbf{C}$} \\
\hline SEm \pm & 0.31 & 0.40 & \multicolumn{2}{|c|}{0.70} \\
\hline CD at $5 \%$ & 0.91 & 1.18 & \multicolumn{2}{|c|}{ NS } \\
\hline
\end{tabular}


Table.2 Effect of pruning intensity and foliar feeding of nutrients on number of shoot per plant

\begin{tabular}{|c|c|c|c|c|}
\hline \multirow{2}{*}{ Treatments } & \multicolumn{3}{|c|}{ Pruning (Above ground level) } & \multirow{2}{*}{ Mean } \\
\hline & $25 \mathrm{~cm}\left(\mathbf{P}_{1}\right)$ & $50 \mathrm{~cm}\left(\mathrm{P}_{2}\right)$ & $75 \mathrm{~cm}\left(P_{3}\right)$ & \\
\hline $\mathrm{C}_{0 \text { - }}$ Control (water spray) & 22.67 & 26.67 & 21.00 & 23.44 \\
\hline $\mathrm{C}_{1-} \mathrm{ZnSO}_{4} \mathbf{0 . 4 \%}$ & 32.00 & 33.33 & 31.33 & 32.22 \\
\hline $\mathrm{C}_{2-} \mathrm{CuSO}_{4} \mathrm{0.4 \%}$ & 29.00 & 29.67 & 28.67 & 29.11 \\
\hline $\mathrm{C}_{3}-\mathrm{K}_{2} \mathrm{SO}_{4} \mathbf{0 . 2 \%}$ & 30.00 & 30.33 & 29.67 & 30.00 \\
\hline $\mathrm{C}_{4-}$ Urea $2.0 \%$ & 32.67 & 33.00 & 30.67 & 32.11 \\
\hline \multirow[t]{2}{*}{ Mean } & 29.27 & 30.60 & 28.27 & \\
\hline & $\mathbf{P}$ & $\mathbf{C}$ & \multicolumn{2}{|c|}{$\mathbf{P} \times \mathbf{C}$} \\
\hline SEm \pm & 0.40 & 0.51 & \multicolumn{2}{|c|}{0.89} \\
\hline CD at $5 \%$ & 1.15 & 1.48 & \multicolumn{2}{|c|}{$\mathrm{NS}$} \\
\hline
\end{tabular}

Table.3 Effect of pruning intensity and foliar feeding of nutrients on number of leaves per shoot

\begin{tabular}{|c|c|c|c|c|}
\hline \multirow{2}{*}{ Treatments } & \multicolumn{3}{|c|}{ Pruning (Above ground level) } & \multirow{2}{*}{ Mean } \\
\hline & $25 \mathrm{~cm}\left(P_{1}\right)$ & $50 \mathrm{~cm}\left(P_{2}\right)$ & $75 \mathrm{~cm}\left(P_{3}\right)$ & \\
\hline $\mathrm{C}_{0}$ - Control (water spray) & 76.00 & 72.33 & 71.00 & 73.11 \\
\hline $\mathrm{C}_{1-} \mathrm{ZnSO}_{4} \mathrm{0.4 \%}$ & 86.33 & 83.33 & 81.00 & 83.56 \\
\hline $\mathrm{C}_{2-} \mathrm{CuSO}_{4} \mathrm{0.4 \%}$ & 83.67 & 82.00 & 81.67 & 82.44 \\
\hline $\mathrm{C}_{3-} \mathrm{K}_{2} \mathrm{SO}_{4} \mathrm{0.2} \%$ & 88.00 & 86.33 & 84.33 & 86.22 \\
\hline $\mathrm{C}_{4-}$ Urea $2.0 \%$ & 92.33 & 91.00 & 88.00 & 90.44 \\
\hline Mean & 85.27 & 83.00 & 81.20 & \\
\hline & $\mathbf{P}$ & $\mathbf{C}$ & \multicolumn{2}{|c|}{$\mathbf{P} \times \mathbf{C}$} \\
\hline SEm \pm & 0.51 & 0.65 & \multicolumn{2}{|c|}{1.13} \\
\hline CD at $5 \%$ & 1.47 & 1.90 & \multicolumn{2}{|c|}{ NS } \\
\hline
\end{tabular}

Table.4 Effect of pruning intensity and foliar feeding of nutrients on reducing sugars (\%)

\begin{tabular}{|c|c|c|c|c|}
\hline \multirow{2}{*}{ Treatments } & \multicolumn{3}{|c|}{ Pruning (Above ground level) } & \multirow{2}{*}{ Mean } \\
\hline & $25 \mathrm{~cm}\left(\mathbf{P}_{1}\right)$ & $50 \mathrm{~cm}\left(P_{2}\right)$ & $75 \mathrm{~cm}\left(\mathbf{P}_{3}\right)$ & \\
\hline $\mathrm{C}_{0-}$ Control (water spray) & 11.52 & 11.93 & 10.57 & 11.34 \\
\hline $\mathrm{C}_{1-} \mathrm{ZnSO}_{4} \mathrm{0.4 \%}$ & 13.29 & 13.76 & 13.25 & 13.43 \\
\hline $\mathrm{C}_{2-} \mathrm{CuSO}_{4} \mathrm{0.4 \%}$ & 12.88 & 13.07 & 12.48 & 12.81 \\
\hline $\mathrm{C}_{3-}-\mathrm{K}_{2} \mathrm{SO}_{4} 0.2 \%$ & 12.92 & 13.13 & 12.73 & 12.92 \\
\hline $\mathrm{C}_{4-}$ Urea $2.0 \%$ & 12.80 & 12.87 & 12.86 & 12.84 \\
\hline \multirow[t]{2}{*}{ Mean } & 12.68 & 12.95 & 12.37 & \\
\hline & $\mathbf{P}$ & $\mathbf{C}$ & \multicolumn{2}{|c|}{$\mathbf{P} \times \mathbf{C}$} \\
\hline SEm \pm & 0.15 & 0.19 & \multicolumn{2}{|c|}{0.33} \\
\hline CD at $5 \%$ & 0.43 & 0.56 & \multicolumn{2}{|c|}{ NS } \\
\hline
\end{tabular}


Table.5 Effect of pruning intensity and foliar feeding of nutrients on total sugars (\%)

\begin{tabular}{|c|c|c|c|c|}
\hline \multirow{2}{*}{ Treatments } & \multicolumn{3}{|c|}{ Pruning (Above ground level) } & \multirow{2}{*}{ Mear } \\
\hline & $25 \mathrm{~cm}\left(\mathbf{P}_{1}\right)$ & $50 \mathrm{~cm}\left(\mathbf{P}_{2}\right)$ & $75 \mathrm{~cm}\left(\mathbf{P}_{3}\right)$ & \\
\hline $\mathrm{C}_{0-}$ Control (water spray) & 14.68 & 15.20 & 13.47 & 14.45 \\
\hline $\mathrm{C}_{1 .} \mathrm{ZnSO}_{4} \mathbf{0 . 4 \%}$ & 16.94 & 17.53 & 16.88 & $\mathbf{1 7 . 1 2}$ \\
\hline $\mathrm{C}_{2-} \mathrm{CuSO}_{4} \mathrm{0.4 \%}$ & 16.42 & 16.65 & 15.90 & $\mathbf{1 6 . 3 2}$ \\
\hline $\mathrm{C}_{3}-\mathrm{K}_{2} \mathrm{SO}_{4} 0.2 \%$ & 16.46 & 16.73 & 16.22 & $\mathbf{1 6 . 4 7}$ \\
\hline $\mathrm{C}_{4-\text { Urea }} 2.0 \%$ & 16.32 & 16.40 & 16.38 & $\mathbf{1 6 . 3 7}$ \\
\hline \multirow[t]{2}{*}{ Mean } & 16.16 & 16.50 & 15.77 & \\
\hline & $\mathbf{P}$ & C & \multicolumn{2}{|c|}{$\mathbf{P} \times \mathbf{C}$} \\
\hline SEm \pm & 0.19 & 0.25 & \multicolumn{2}{|c|}{0.43} \\
\hline CD at $5 \%$ & 0.56 & 0.71 & \multicolumn{2}{|c|}{1.25} \\
\hline
\end{tabular}

Table.6 Effect of pruning intensity and foliar feeding of nutrients on fruit yield per hectare (q/ha)

\begin{tabular}{|c|c|c|c|c|}
\hline \multirow{2}{*}{ Treatments } & \multicolumn{3}{|c|}{ Pruning (Above ground level) } & \multirow{2}{*}{ Mean } \\
\hline & $25 \mathrm{~cm}\left(\mathbf{P}_{1}\right)$ & $50 \mathrm{~cm}\left(\mathbf{P}_{2}\right)$ & $75 \mathrm{~cm}\left(\mathbf{P}_{3}\right)$ & \\
\hline $\mathrm{C}_{0-}$ Control (water spray) & 47.26 & 50.50 & 47.20 & 48.32 \\
\hline $\mathrm{C}_{1 .} \mathrm{ZnSO}_{4} \mathbf{0 . 4 \%}$ & 61.61 & 66.55 & 61.61 & 63.26 \\
\hline $\mathrm{C}_{2-} \mathrm{CuSO}_{4} \mathrm{0.4 \%}$ & 60.03 & 64.80 & 60.42 & 61.75 \\
\hline $\mathrm{C}_{3-} \mathrm{K}_{2} \mathrm{SO}_{4} 0.2 \%$ & 59.31 & 64.00 & 63.17 & 62.16 \\
\hline $\mathrm{C}_{4-}$ Urea $2.0 \%$ & 61.24 & 66.10 & 61.84 & 63.06 \\
\hline \multirow[t]{2}{*}{ Mean } & 57.89 & 62.39 & 58.85 & \\
\hline & $\mathbf{P}$ & $\mathbf{C}$ & \multicolumn{2}{|c|}{$\mathbf{P} \times \mathbf{C}$} \\
\hline SEm \pm & 1.09 & 1.41 & \multicolumn{2}{|c|}{2.45} \\
\hline CD at $5 \%$ & 3.17 & 4.09 & \multicolumn{2}{|c|}{7.09} \\
\hline
\end{tabular}

The interaction effect of pruning levels and chemicals spray on total sugar contents was found significant and the maximum total sugar contents (17.53) were recorded with spray of $\mathrm{ZnSO}_{4}(0.4)$ along with pruning at 50 $\mathrm{cm}$ above ground level while, value was minimum (13.47) with water spray along with pruning at $75 \mathrm{~cm}$ above ground level. Similar results were also reported by Singh et al., (1979) in grapes and Bhatia and Yadav (2005) in ber.

The maximum (Table 6) fruit yield per ha (63.26) was recorded with foliar spray of $\mathrm{ZnSO}_{4}(0.4 \%)$ and statistically at par with application of Urea (2.0) and $\mathrm{K}_{2} \mathrm{SO}_{4}(0.2)$.
However, value with respect to fruit yield per hectare was noticed minimum (48.32) under water spray. In case of pruning, fruit yield was significantly influenced by various pruning levels. However, the maximum fruit yield per hectare (62.39) was recorded with pruning at $50 \mathrm{~cm}$ above ground level followed by pruning at $75 \mathrm{~cm}$ above ground level while, minimum (57.89) fruit yield per hectare was recorded with pruning at $25 \mathrm{~cm}$ above ground level. The interaction of pruning level and chemical spray on fruit yield (quintal) per hectare was found to be significant. The highest yield (66.55) was noted with combined effect of $\mathrm{ZnSO}_{4}$ (0.4) along with pruning at $50 \mathrm{~cm}$ above ground level while, 
value was minimum (47.20) with water spray along with pruning at $75 \mathrm{~cm}$ above ground level. The increase in yield due to increase in number of shoots per plant, number of fruiting nodes per shoots, number of fruits per node and increased yield per plant which contributed towards such an increase in average yield per hectare. The present findings were in conformity with Ali et al., (1991) in guava and Singh et al., (2001) in aonla.

From above results it may be concluded that maximum shoot length and number of shoots per plant was noted with $\mathrm{ZnSO}_{4}(0.4 \%)$ along with $25 \mathrm{~cm}$ pruning level above ground fallowed by pruning at $50 \mathrm{~cm}$ above ground level. However, more number of leaves per shoot and internodal length was associated with pruning $25 \mathrm{~cm}$ along with Urea $(2.0 \%)$ treatment. Better response of $\mathrm{ZnSO}_{4}(0.4 \%)$ treatment was noted with yield and yield attributes along with pruning at $50 \mathrm{~cm}$ above ground level. The sugar content were better with $\mathrm{ZnSO}_{4}(0.4 \%)$ treatment along with 50 $\mathrm{cm}$ pruning above ground level closely followed by spray of $\mathrm{K}_{2} \mathrm{SO}_{4}(0.2 \%)$ along with pruning at $50 \mathrm{~cm}$ above ground.

\section{References}

Ali, W., Pathak, R.A. and Yadav, A.L., 1991. Effect of foliar application of nutrients of guava (Psidium guajava, L.) cv. Allahabad Safeda. Progressive Horticulture, 23(1-4): 18-31.

AOAC. 1990. Official Methods of Analysis. $15^{\text {th }}$ edn. Association of Official Analytical Chemist, Washington, D.C.

Bhatia, B.S. and Yadav, P.K., 2005. Effect of foliar application of Urea and NAA on fruit yield and quality of ber (Zizyphus mauritiana) Nat. Sem. Commercialization of Horticulture in Nontraditional areas. Organized by Central Institute of AridHorticulture,
Bikaner, (Rajasthan) from 5-6: 119.

Gomez, K.A. and Gomez, A.A., 1984. Statistical Procedure for Agriculture Researcher, second edition, John Wiley and Sons, New York.

Kumar, S., Kumar, S. and Verma, D.K. 2004. Effect of micronutrients and NAA on yield and quality of litchi (Litchi chinesis Garttn. Sonn) cv. Dehradun fruits Abstr: In proc. of International Seminar on Rec. Trend in Hi. Tech Hort. and PHT, organized by CSAUAT, Kanpur from Feb. 4-6: 193.

Rathore, A.C., Raizada, A. and Jayaprakash, J. 2008. Performance of phalsa (Grewia subimaequalis Lin.) through integrated nutrient and canopy management on saline soil of the Indo-Gangetic Plains. Indian J. Soil Conservation, 36(1): 4247.

Sharma, J.R, Kaushik, R.A. and Panwar, RD. 2008. Influence of nitrogen, phosphorus and potassium on yield and physicochemical properties of phalsa. Indian J. Horticulture, 65: 326-27.

Singh, A.K. and Singh, G.N. 2003. Effect of different levels of pruning and nitrogen on growth and yield of phalsa (Grewia subinequalis D.C.). Orissa J. Horticulture, 31: 86-88.

Singh, H.K., Srivastava, A.K., Dwivedi, R. and Kumar, P., 2001. Effect of foliar feeding of micronutrients on plant growth, fruit quality, yield and internal fruit necrosis of aonla (Emblica officinalis Gaertn.) cv. Francis. Progressive Horticulture, 33(1): 80-83.

Singh, L., Singh, S. and Singh, B. 2006. Effect of pruning levels and growth regulators on vegetative and fruit characteristics of phalsa during summer and winter crops under Punjab conditions. Proc. National Symp. Production, Utilization and Export of Underutilized Fruits with Commercial Potentialities, Kalyani, Nadia, West 
Bengal, 22- 24 November, 2006, pp. $132-44$.

Singh, P., Singh, H.K., Vishwanath, and Pratap, B. 2009. Response of foliar feeding of nutrients on growth yield and quality of phalsa (Grewia subinaequalis D.C.) fruits. Annals of Horticulture, 2(1): 69-71.

Singh, R., 1992. Fruits, National Book Trust
A-5 Green Park, New Delhi110016.

Singh, S.K. and Singh, H.K., 2008. Pruning behavior in aonla (Emblica officinalis Gaertn.) cv Narendra aonla-2. Environ. Ecol., 26(3): 1039-1041.

Singh, T.P., Yamdagni, R. and Jindal, P.C. 1979. A note on the effect of potassium sprays on quality of grapes cv. Perlette. Haryana J. Sci., 8(3-4): 207-208.

\section{How to cite this article:}

Shashank Singh and Singh, H.K. 2017. Influence of Pruning Intensity and Foliar Application of Nutrients on Growth, Yield and Sugar Content of Phalsa (Grewia subinaequalis D.C.). Int.J.Curr.Microbiol.App.Sci. 6(3): 2221-2227. doi: https://doi.org/10.20546/ijcmas.2017.603.253 